University of Nebraska - Lincoln

DigitalCommons@University of Nebraska - Lincoln

Papers in the Earth and Atmospheric Sciences

Earth and Atmospheric Sciences, Department

1939

\title{
CLASSIFICATION OF THE TERTIARY SYSTEM IN NEBRASKA
}

Alvin Leonard Lugn

University of Nebraska-Lincoln

Follow this and additional works at: https://digitalcommons.unl.edu/geosciencefacpub

Part of the Earth Sciences Commons

Lugn, Alvin Leonard, "CLASSIFICATION OF THE TERTIARY SYSTEM IN NEBRASKA" (1939). Papers in the Earth and Atmospheric Sciences. 371.

https://digitalcommons.unl.edu/geosciencefacpub/371

This Article is brought to you for free and open access by the Earth and Atmospheric Sciences, Department of at DigitalCommons@University of Nebraska - Lincoln. It has been accepted for inclusion in Papers in the Earth and Atmospheric Sciences by an authorized administrator of DigitalCommons@University of Nebraska - Lincoln. 
BULLETIN OF THE GEOLOGICAL SOCIETY OF AMERICA

VOL. 5O. PP. 1245-1276. 1 PL.

AUGUST 1,1939

\title{
CLASSIFICATION OF THE TERTIARY SYSTEM IN NEBRASKA
}

\author{
BY A. L. LUGN
}

CONTENTS

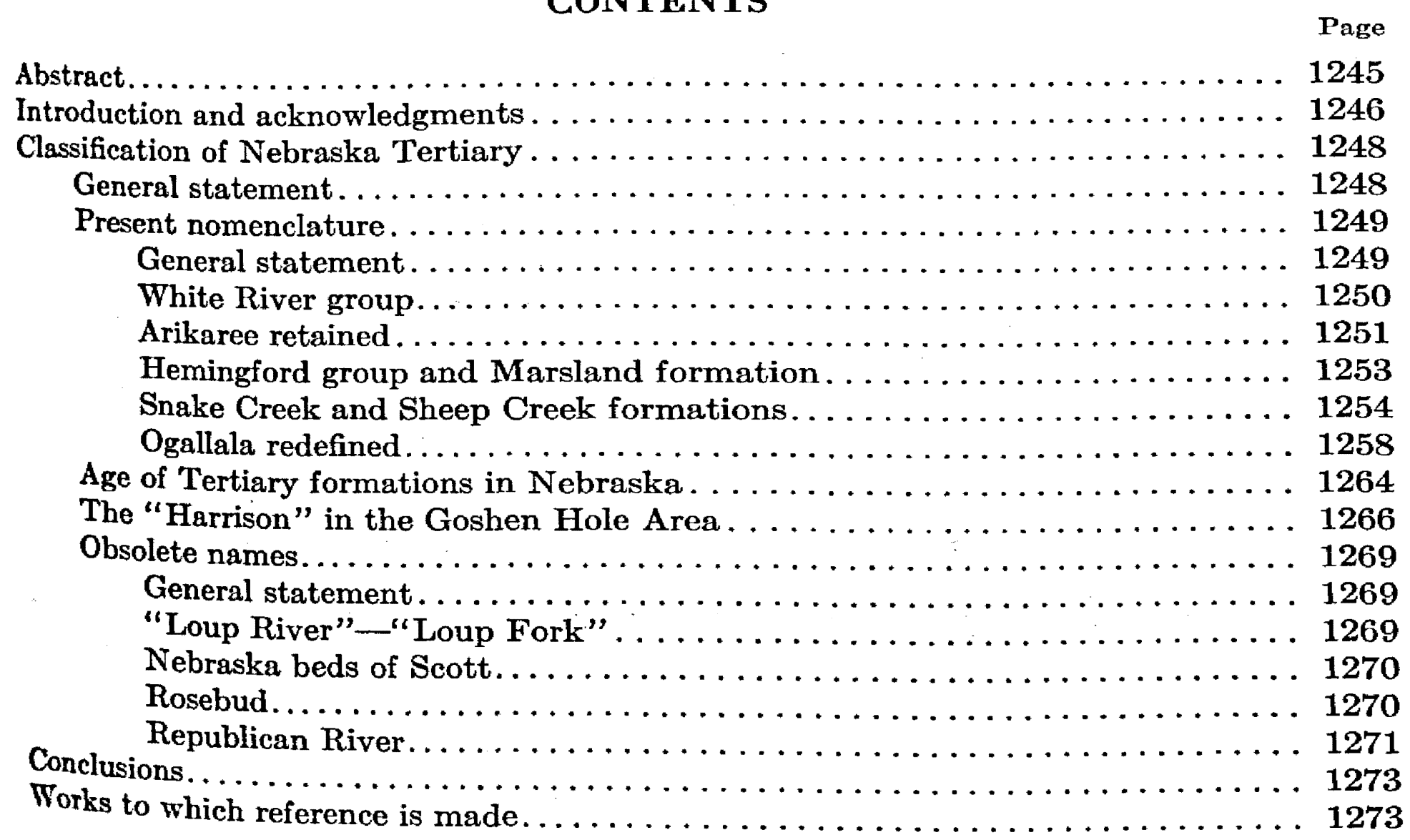

Plate

ILLUSTRATION

1. Tertiary geologic map of western Nebraska

Facing page

1245

\section{ABSTRACT}

This paper presents the results of almost continuous research by the Nebraska State than 10 years, with on Tertiary stratigraphy in Nebraska during a period of more clature. Cogent reasons are attention to the present acceptable stratigraphic nomenas Thite ranking. "Loup, Arikaree, and Ogallala, all now redefined and elevated to group are considered obsolete. "Loup River", "Nebraska beds", and "Republican River" lation is noted. The table application of fossil seed zones to problems of correTertiary stratigraphy table of Tertiary formations of Nebraska summarizes the 


\section{INTRODUCTION AND ACKNOWLEDGMENTS}

This paper contains in the main the conclusions of the writer, who has been engaged in almost continuous research on Tertiary stratigraphy in Nebraska since 1929, regarding the classification and naming of the stratigraphic units of the Tertiary system in this State. The classification and nomenclature presented herein are now acceptable to and used by the Nebraska State Geological Survey. Stratigraphic methods can be successfully applied to problems of sedimentation sequence and faunal succession in the High Plains Tertiary deposits. The orderly arrangement and succession of "formations", so clearly set forth by Darton in several well-known publications more than 30 years ago, are realities; and it is neither necessary nor desirable to depend entirely on vertebrate fossil evidence for the determination of the age relations of either the sediments or the faunas. The multiplicity of names for "formations," "beds", "localities", and "faunas" introduced into the literature of the continental Tertiary during the past 40 years has been due to the more or less general belief that the "beds" could not be traced very far in any direction and that ordinary stratigraphic methods could not be applied to the Tertiary deposits of the High Plains. These have been erroneous assumptions, and the duplication of names is now a source of considerable annoyance.

Plate 1 is a somewhat detailed geologic map of the western part of Nebraska, in the main west of the one hundred second meridian. It has seemed advisable becatse of the limitations of the scale of the map to group certain Cretaceous formations under a single symbol; also, to map the Gering and the Monroe Creck formations as a unit because of the narrowness of the Gering outerop areas. The Valentine and Ash Hollow formations are also mapped as a unit; and the Sidney gravel and the Fimball formation are shown together under another symbol. Nevertheless, the map is believed to show in considerable detail and quite accurately the areal distribution of most of the Tertiary formations.

The IBrule clay extends eastward from the area included in Plate 1 along the Niobrara River Valley for more than 100 miles, and for perhaps: not much more than 75 miles along the North Platte River Valley. It is present under cover throughout most of the western half of Nebraska. The Miocene formations seem to extend for only a few miles to the east in Cherry County at the north. Formations of the Ogallala group, mainly the Valentine and Ash Hollow, occur under nearly all the Sand Hills region in north-central Nebraska; and they extend far to the east of the Sand Hills under a cover of Pleistocene deposits. Outcrops of mainly the Ash Hollow and Valentine formations are fairly continuous in the 
Jiobrara River Valley and tributarics as far cast as Fnox County, and in the Republican River Valley and tributaries as far east as Red Cloud in Webster County.

Certain limitations in locating formationa I boundaries in the field are responsible for varying degrees of accuracy on the map. Most important are: unexposed contacts under covered slopes; similarity of lithology and lack of contrast between succeeding formations at some plices, often because of the presence of reworked older material in an overlying formation; lack of exact knowledge of faunal horizons in some places; inaccessibility in some areas under existing field conditions at the time of mapping; time limitations in the field, sometimes complicated by inclement reather; in some places insufficient knowledge to date to locate all contacts with great exactness; and lastly the fact that the field mapping has been carried out by reconnaissance methods on base maps of only one inch to the mile and without the use of a plane table. The scale of the present published map is itself a limitation on the detailed accuraey of some of the formation boundaries, which had to be somewhat generalized in certain localities.

Athough future more detailed mapping in local areas by more precise methods will necessitate many revisions, it is hoped that this map may be found useful. A number of small outliers of lower Ogallala (Valentine and Ash Hollow) formations occur in northeastern Box Butte County but are not shown. Certain small inliers of possible Monroe Creck formation, which may indicate anticlinal structures similar to the Agate anticline, within the Hemingford area are not all shown.

The writer has had the benefit of close cooperation with many other geologists and paleontologists during the entire period of his studies on the Tertiary system in Nebraska. Space does not permit detailed acknowledgments at this time. Dr. G. E. Condra, State Geologist of Nebraska, under whose direction this work has been done, has cooperated with the writer and given valuable counsel at all times. Dr. R. C. Hoore, State Geologist of Kansas, also has cooperated and aided in many rays. Special credit for cooperation in the field work or consultation in the office or both is due M. K. Elias, C. Bertrand Schultz, Thompson MI. Stout, Morris Skinner, Charles Falkenbach, F. Walker Johnson, Gilbert Lueninghoener, Emory L. Blue; Eugene Reed, Assistant State Geologist of Nebraska, and other members of the Nebraska State Geological Survey; L. K. Wenzel, O. E. Meinzer, and R. C. Cady, United States Geological Survey; E. H. Colbert, R. A. Stirton, Harold J. Cook, Ted Galusha, Jack Nilson, and indirectly to Childs Frick and E. H. Barbour; also to many loeal eitizens in Nebraska and Kansas and to others. Much credit is due the authors of a voluminous literature dating from F. V. Hayden, 
Joseph Leidy, O. C. Marsh, and E. D. Cope, to N. H. Darton, H. F. Osborn, W. D. Matthew, W. B. Scott, and many others. Wilmer R. Shirk has ably assisted in the preparation of the map.

\section{CLASSIFICATION OF NEBRASKA TERTIARY}

GENERAL STATEMENT

Classification of the stratigraphic divisions of the Tertiary of Nebraska is not simple. Many names have been applied to "beds" in numerous places within this State and in other areas. Many of these published names are recorded with only the most meager notes on the geology or even on the particular exposure in question. It is difficult in many cases to determine how the name was intended; it may have been meant to name only a fauna, or a locality, or perhaps it was applied to certain "beds".

The nonchalance with which "beds" have been given names is well illustrated by a quotation from Barbour (1917, p. 499). After pointing out that the heavy rains of spring and summer of 1915 had exposed a Tctrabclodon in a recent gully near Bristow, Nebraska (Boyd County), he later states,

"The deposit is of Pliocene age equivalent to the Snake River of Cherry County. and the lower Devil's Gulch beds of Brown County. For convenience we shall call these the Bristow beds."

Some confusion is inevitable when the locality, faunal, or stratigraphic use of a name is not clearly defined by its author. The writer is primarily concerned with the stratigraphic classification of the Tertiary lithologic units in Nebraska. When the stratigraphic relationships are fully understood, the faumas can be properly and correctly related and named, whether the stratigraphic names or others are used. The Nebraska Survey, in determining its acceptance of stratigraphic names on the basis of priority, is making every effort to differentiate names which have been applied in a strictly stratigraphic sense from names which, though older, were applied in only a geographical or faunal sense and for the most part have only locality significance. It has tried to settle on a nomenclature for its Tertiary stratigraphy which will be generally acceptable and whose units are mappable. Obviously, all the faunal names cannot be applied as stratigraphic names, and, regardless of the original application of any name, only those which apply to mappable units can survive as formational or group names.

Many strictly "local" names have been applied to exposures in one sense or another, in some cases in several ways, and many if not most of them are so inappropriate or unsuitable for stratigraphic purposes that it is impossible to retain all names for stratigraphic use, and for various 
reasons it is impossible to respect absolute priority in all cases. The only alternative is to try to be as considerate of the custom of priority as possible and at the same time to salvage those names which are most appropriate and suitable and which have also gained most general usage, are best understood, and have suffered the least abuse.

Also, the Nebraska State Survey considers it proper and expedient in some instances to retain a well-established name that has long been in use and is widespread in the literature in preference to some hazy, obscure name, which by some manner might be shown to have had slightly prior usage in some little-known publication, or which has not gained wide recognition and use, or has been largely abandoned. An appropriate, well-established name like Arikaree should be retained, even if it has been used in some form for some other part of the geologic section but has become obsolete or abandoned for that purpose. It is true that Cragin (1896, p. 49-52) applied the term "Arickaree shales" to some of the lower part of the Fox Hills division of the upper Cretaceous. However, Cragin himself abandoned the name, and it never gained general usage. Darton saw no objection to reviving the term "Arikaree" at a little later time and supplying his own definition (Darton, 1903, p. 17). Likewise Cragin's (1896) "Platte series" for the upper Cretaceous on a par with "Comanche series" for the lower Cretaceous never gained acceptance. This old term also has recently been resurrected, redefined, and applied to another part of the geologic section (Lugn, 1935, p. 30-31, 88-127).

The Nebraska Geological Survey adheres to a policy of cooperation in regard to all questionable problems touching matters of nomenclature, stratigraphy, and paleontology. Its policy is to reach agreement in these matters first with neighboring State surveys and then to seek approval from the United States Geological Survey. Every effort is made to define members, formations, groups, series, and systems; also, horizons and zones in the strictest sense according to the principles and rules laid down by the committee on nomenclature and stratigraphy, which was initiated by the Association of American State Geologists in 1930. This committee now represents not only the above association but also the United States Geological Survey, the Geological Society of America, and the American Association of Petroleum Geologists. A report has been published (Ashley, 1933).

\section{PRESENT NOMENCLATURE}

General statement.-A skeleton table (Table 1) of the Tertiary stratigraphic divisions now acceptable in Nebraska and Kansas and also in adjoining regions of the Great Plains is printed in this paper. Only brief 
discussion can be included here. The Tertiary of this region is divisible into four natural lithologic groups, each of which represents a separate and distinct cycle of sedimentation. The White River, Arikaree, and Ogallala are familiar terms (Lugn, 1938). The White River group remains unchanged. ${ }^{1}$ The Arikaree group has been redefined to include the Gering formation as the basal channel development at the beginning of the Arikarce cycle of sedimentation. This redefinition of the Arikaree has been announced by Schultz (1938).

White River group. - White River is the classic name for the Oligocene formations and "beds" of the Big Badlands and also for the remainder of the central and northern High Plains and in most of the Rocky Mountain region. The name has been used with little change from the early writings of Hnyden (1869), Leidy, Marsh, and Cope, down to the present time (Simpson, 1933; Osborn, 1929; Osborn and Matthew, 1909). The White River group has been very conveniently and satisfactorily zoned on the basis of its contained vertebrate fossils (Osborn and Matthew, 1909; Osborn, 1929). It seems desirable to retain these faunal zones for the present at least. The White River group in Nebraska attains or excecds a thickness of 700 feet.

The lower White River has come to be generally known as the "Titanotherium beds", composed of clay, silt, and channel sandstones. A conflomerate 10 feet or more thick is present at the base of the division at most places in northwestern Nebraska. This division was designated the "Chadron formation" by Darton $(1899,1903,1905)$. The Chadron formation is retained with the same significance as Darton ascribed to it. It ranges in thickness from less than 50 feet to more than 100 feet and is exposed low on the slopes north of the Pine Ridge in northwestern Nebraska and in a small area in western Scotts Bluff County. The clay and silt beds grade from greenish to pink, and the sandstones may be grayish and greenish to brown.

The midelle white River consists of clays, silty and sandy clays, and channel sandstones. The clay's are commonly referred to as "Orcodon" clays, and the sandstones as "nodular sandstones" and "Metamylnodon sandstones" (Osborn, 1929; Osborn and Matthew, 1909). The middle white River beds are as much as 125 feet or more thick where exposed in northwestern Nebraska and are predominantly pink and greenish with brownish tints in the sandstones. The upper White River division consists mainly of "Leptauchenia clay" containing ser-

\footnotetext{
Nesw member subdivision names for the Brule formation are now under consideration and will be intrombel in forthcoming publications by T. M. Stout, C. Bertrand Schultz, and the writer.
} 
eral layers of impure volcanic ash with the "Protoceras sandstones" at the base. In Nebraska this upper Leptauchenia zone, predominantly pink, ranges from 250 feet to perhaps 500 feet in thickness and is extensively exposed in the Pine Ridge slopes, in the North Platte River Valley, and in the Lodgepole River Valley. Darton (1899, 1903, 1905) included the middle and upper White River divisions in his Brule clay, which remains unchanged at the present. These two divisions of the Brule soon may be given formational or member designations. The Brule clay in Nebraska ranges from 350 feet to more than 600 feet in thickness.

Arikaree retained.-It seems desirable to retain and to "resurrect", if that is necessary, the well-known name Arikaree (Darton, 1899, 1903, 1905) for the main body of Miocene deposits in the "central plains area". Redefined as the "Arikaree group", it will prove to be a most useful term. It seems to be the most suitable group name for a large part of the Miocene over a very large area. Unfortunately Simpson (1933) and others (Schlaikjer, 1935) regarded "Arikaree" as an "obsolescent" term. It has never been so regarded by the writer and many other geologists in Nebraska and adjoining States, nor by the Nebraska Geological Survey. The Arikaree group now comprises the Gering, Monroe Creek, and Harrison formations.

The Arikaree "formation", as Darton (1899, 1903, 1905) called it, was defined by him as $(1905$, p. 176) "the principal component of the scries formerly termed "Loup Fork'" and as consisting in the main of 400 to 500 feet of fine, gray sands containing hard solid, dark gray, "tubular" concretions, occurring singly or in horizontal zones. The "pipy" concretions are present in two thick zones-in the lowermost 200 feet or more (now the lower part of the Monroe Creek formation) and in a higher zone about 100 feet thick from 100 to 200 feet below the top of the "formation" (now in the Harrison formation). Darton (1903, p. 17) stated that the Daemonelix of Barbour occur in the upper portion of the Arikaree. He did not at first include in the Arikaree formation anything above the Daemonelix beds.

The present Arikaree group, including also the Gering formation, rests with pronounced erosional unconformity on the Brule clay, mainly in contact with the Leptauchenia zone. The relief on the Brule surface is more than 250 feet within small areas. The deeper pre-Arikaree valleys contain the Gering formation of bedded and cross-bedded fine to coarse channel sands and gravels. The higher levels of the old Brule surface are overlapped generally by some part of the Monroe Creek formation. The maximum thickness of the Gering formation 
is approximately 230 fect at a location about 6 miles south and a little west of Gering, Nebraska. Darton (1905, p. 177) stated that,

"it is believed that the Gering beds represent the first deposits of Arikaree times, separable only in areas where they consist of coarse material laid down in channels,"

but he did not include it with the Arikaree. The Gering channel deposits are best known and perhaps most fully developed in the North Platte River Valley in Scotts Bluff and Morrill counties and in the slopes of the Pine Ridge across northern Sioux and Dawes counties. The Gering horizon seems to change to a floodplain facies closely resembling the Monroe Creck formation from Chadron eastward across northern Sheridan County.

The Monroe Creck formation was defined by Hatcher (1902) as a lower sublivision of the Arikaree from outcrops in Monroe Creek canyon in the Pine Ridge a few miles north of Harrison, Nebraska. The Monroc Creck formation along the Pine Ridge from Harrison to the Crawford vicinity rests conformably on from 100 to 200 feet of Gering channel deposits. The thickness of the Monroe Creek formation in this area ranges from about 285 feet to more than 360 feet. The lower part, from 185 to about 220 feet, is composed of fine- to medium-textured gray sand, massively bedded for the most part, and permeated by large, heavy, "pipy" concretions, the "lower" pipy zone. Some cross-bedding may be observed in the lower part of the formation.

The upper part of the Monroe Creek formation, 100 to nearly 150 feet thick, consists of compact fine sandy silt and clay, pinkish to buff, containing many layers of more or less cemented concretions and many isolated nodular concretions. The more solid concretion layers, about a foot thick, are quite flat and horizontal along their upper surfaces; but peculiar pendant irregular concretionary structures extend downward for a foot or more from the lower side. Many of the isolated nodular concretions are elongated and "characteristically upright in position" (Cook, 1915). The concretions in the upper part of the Monroe Creck are characteristically different from the heavy, "pipy" ones in the lower part of the formation or the "pipy" concretions in the lower part of the next overlying Harrison formation.

The Inarrison formation first was differentiated as an upper subdivision of Darton's Arikaree by Hatcher (1902). It rests conformably on the Monroe Creek formation, and the top of it is at the general level of the High Plains in the vicinity of Harrison, Nebraska. It consists of about 200 feet or slightly less of fine, mostly unconsolidated, for the most part massive, gray sand. The lower part, about 100 feet thick, also is permeated by horizontal "pipy" concretions, the "upper" pipy zone, similar to but not as large and "heavy" as the big "pipy" 
structures in the lower part of the Monroc Creck formation. The upper 100 feet of the Harrison formation contains the Dacmonclix structures and considerable "fossilized" vegetal remains, which take a stringy, rod-like, or nodular form. Less of this stringy material is found in the lower part associated with the large pipy concretions. A thin characteristic agatized limestone bed caps the formation. Hatcher's Harrison did not include the so-called "upper Harrison" (now Marsland formation), which came into use a little later (Peterson, 1906; Cook, 1915; Schultz, 1938).

Thick fills of channel sediment, 50 to more than 150 feet thick, occur in the Harrison formation and in general resemble quite closely the lithology of the channel deposits of the older Gering and those of younger formations, as in the Sheep Creek, Valentine, Ash Hollow, or Snake Creek. The well-known fossil bone deposit at Agate is a part of a Harrison channel fill near the middle of the formation. Another deep channel fill, perhaps stratigraphically a little higher than that at Agate, occurs closely associated with fossil beds a few miles south of Angora; and a thick Harrison(?) fill seems to extend across the southern part of Box Butte County.

Hemingford group and Marsland formation.-The Hemingford group is a new division suggested by C. Bertrand Schultz, Assistant Director, Nebraska State Museum, and concurred in by the Nebraska Geological Survey and the writer. It includes the Marsland and Sheep Creek formations. The Marsland formation is a recent term given by Schultz (1938), who has stated fully the basis for the use of this term and the redefinition of the Arikaree. He writes:

\begin{abstract}
"To the deposits ('upper Harrison beds') which immediately overlie the Arikaree group and which are faunally and lithologically distinct from the typical Arikaree, the writer suggests the name Marsland formation. This formation is best exposed in Nebraska in the region about Marsland (southwestern Dawes County) along the Niobrara River where it includes some 150 feet of buff and gray, soft sandstones. The Marsland consists, in part, of valley fills, and in places seems to mantle the slopes of certain large valleys. The upper part of the Marsland formation in this region is more gritty and is mostly buff-colored. The fauna of the Marsland formation seems to be intermediate between that of the Harrison formation and the overbying Sheep Creek formation and perhaps should provisionally be considered as the lower part of the upper Miocene. The characteristic fossils are Merycochoerus, Merychyus, Aletomeryx, Oxydactylus, and advanced Parahippus, or (and) Merychippus, etc."
\end{abstract}

The Harrison formation is to be understood in the sense in which it was originally defined by Hatcher (1902). The Marsland formation, the buff to reddish-brown beds which overlie the Arikaree group, was never included in the Harrison formation of Hatcher; neither was the Marsland a part of Scott's "Nebraska beds", as Hatcher thought, nor was it included 
in Darton's Arikaree (Darton, 1903) except as he accepted Hatcher's subdivisions in a later report (Darton, 1905). Darton states:

\begin{abstract}
"According to Hatcher (1902) the Arikaree formation in the western portion of Pine Ridge is divisible into three distinct horizons, comprising the Monroe Creek beds, which overlie the Gering sandstones north of Harrison, Nebraska; the Harrison beds, which constitute the surface of Pine Ridge in the vicinity of Harrison; and the Nebraska beds of Scott, which occur along Niobrara River south of Harrison."
\end{abstract}

It should be evident that the stratigraphie relationships of the Marsland beds have not been very clearly understood. Hatcher may have meant the beds now called the Marsland formation, but they were not the "Nebraska beds" of Scott. The term "Nebraska beds" (perhaps correlative of the Valentine formation) is no longer in use (Simpson, 1933).

I Iowever, even though Darton (1905) thought that Hatcher (1902) meant to include the "Nebraska beds of Scott, which occur along the Niobrara River south of Harrison", in the Arikaree, reference to Hatcher's (1902) original paper does not seem to substantiate this conclusion. He states clearly of the Arikaree that, "it is lithologically and faunally divisible into two easily distinguishable horizons". He undoubtedly meant to include in the Arikaree the Monroe Creek and the Harrison beds (in the Intcher sense) but he apparently did not intend to include the "Nebraska beds" of Scott, as Darton seems to have thought. Hatcher suggested in the same paper that the Arikaree should include only the Gering and Monroe Creek beds; and that the Harrison should be placed with the Nebraskn beds (as he then believed them to occur) and the Ogallala to constitute a redefined Loup Fork group. Hatcher's suggestions apparently were not accepted and did not come into general use.

Therefore, these buff to reddish-brown beds have never had a proper name until the term Marsland was proposed recently (Schultz, 1938). The application of the name "upper Harrison" to these beds by Peterson (1906) and others (Cook, 1915) in more recent years has been unfortunate because these beds (Marsland) have no very close stratigraphic or faunal relation to the true Harrison (in the Hatcher sense) and are separated from the underlying Harrison formation by the most significant and important structural and erosional unconformity within the Miocene scries in western Nebraska. The time of the major folding which produced the Agate anticline and certain other structures in western Nebraska scems to have been post-Harrison pre-Marsland.

Snake Creck and Shecp Creck formations.-These formations were defined and named first by Matthew and Cook (1909) and further described and discussed in several papers (Cook, 1915; Matthew and Cook, 1918; Matthew, 1923, 1924). The type locality for both of these formations 
is in south-central Sioux County, Nebraska. The Sheep Creek beds were said to lie unconformably on

"Lower Miocene, equivalent to the Daemonelix Beds of the Niobrara valley" [Harrison formation]. . They consist of soft fine-grained sandy "clay's' of a light buff color, free from pebbles, and containing harder calcareous layers"

(Matthew and Cook, 1909, p. 362).

Matthew and Cook (1909) considered the Snake Creek beds "the remains of a formation" which they regarded as an "outlier of the Ogallala". The Snake Creek formation was said to lie on "the eroded surface of the Sheep Creek beds" and it comprised mainly channel-fill deposits, lacking in the usual amount of calcareous cementing material typical of the "mortar beds" farther south. Of the Snake Creek beds,

"they are composed of a clean sand, with gravel scattered through it, especially in certain layers, and mantling the eroded surface of the Sheep Creek beds"

(Matthew and Cook, 1909, p. 363).

It is unfortunate that the apparent clarity with which Matthew and Cook (1909) at first differentiated these two formations did not always characterize later writings (Matthew, 1923, 1924). Confusion has resulted in the minds of other workers (Simpson, 1933), especially because of the "mixed" faunal lists which have resulted from mixed collections from the Sheep Creek-Snake Creek locality.

It seems evident that the typical "Snake Creek" formation, or at least the so-called "upper Snake Creek", is definitely correlative with some part of the upper Ogallala group. Unfortunately, "Snake Creek" has been incorrectly (?) applied to beds, mainly channel fills, as late as Pleistocene and to other beds as old as Miocene. Much of the Miocene "Snake Creek" or perhaps the so-called "lower Snake Creek" seems to be in part not Snake Creek at all but Sheep Creek channel beds in place and in proper stratigraphic sequence. Also, some of the Miocene and "Sheep Creek" vertebrate fossils collected from "Snake Creek" channel deposits have come from very large blocks of Sheep Creek formation, which were broken away from the banks of the Snake Creek streams. These large blocks of rock have dimensions of 10 to 20 feet or more and were never broken up or disintegrated by the Snake Creek rivers. They lie buried in the younger silt and sand, the true Snake Creek sediment, which is always channel-fill material.

The Sheep Creek formation consists of channel gravels and sands, fine silty sand, silt and clay, and harder caliche beds of widely ranging textural characteristics, all of which fill for the most part narrow valleys or ravines to depths ranging from 30 or 40 feet to 140 feet or more. These deposits, many of which are isolated and unconnected, are widespread throughout quite a large area in northwestern Nebraska; and, in one area 
in the central part of the south half of Sioux County, the Sheep Creek formation extends continuously as a basin deposit of channel, floodplain, and slack-water sediments over about 25 square miles. This seems to be the most extensive and most continuous known occurrence of the Sheep Creek. The areal extent of the Sheep Creek formation no doubt has been larger than at present. The discontinuity of the formation throughout the area of its present distribution probably is due in part to erosion subsequent to deposition.

The total thickness of the Sheep Creek formation exposed above the unconformable contact on the Harrison formation in the type locality, Pliohippus and Aphelops draws in southern Sioux County, Nebraska (Matthew, 1924a), is more than 200 feet. Correlative and stratigraphically overlapping exposures in the southeastern corner of Dawes County, along Pepper Creck and Sand Canyon, clearly indicate that the Sheep Creck stratigraphic and sedimentation unit- the fundamental formational entity-includes about 70 feet of additional beds which are stratigraphieally higher than the uppermost Sheep Creek exposures in the type locality. This increases the stratigraphic thickness of the Sheep Creek formation to at least 270 feet, not including a still higher "member" to be described. It has been mainly the upper part of the Sheep Creek (mostly from about 100 feet below and on a distinctive dark-gray volcanic ash 2 to 3 feet thick) which has been called by some the "lower Snake Creck beds" (Matthew, 1924a) but which in reality constitutes the latest deposits of Sheep Creck sedimentation.

The Sheep Creck formation as now understood can be zoned on the basis of three or four fairly distinctive species of fossil grass seeds, genus Stipidium, with at least one species of fossil Berriochloa, into at least three floral or fossil seed zones. No physical field evidence or faunal data are known which would justify the subdivision of the Sheep Creek formation into new and smaller formational divisions. Floral and faunal zones and member subdivisions may be justifiable. Complete details on the zoning of the Sheep Creek formation will be published in a forthcoming bulletin of the Nebraska State Geological Survey.

The Sheep Creek formation, according to much of the literature, would secm to be of medial to late Miocene age. That it is of late upper Miocene age secms quite probable at present. Many vertebrate fossils supposedly collected in Sheep Creck beds have actually come from the underlying older Marsland formation or from the still older Harrison. This has contributed to the difficulty of dating the true Sheep Creek deposits. Confusion as to the age and possible contemporaneity of parts of the Shcep Creck formation with channel fills sometimes regarded as "Snake Creek channels" has been due to a mistaken notion that all the "channel" 
deposits in the type area (Matthew, 1923, 1924) were Snake Creek and that the slack-water and floodplain deposits were Sheep Creek; that is, the so-called "Snake Creek" (channel-filling deposits) and the "Sheep Creek" (slack-water and floodplain materials) were only facies developments of the same sedimentary deposit, a conception entirely contrary to the first definition and description (Matthew and Cook, 1909). Matthew (1923), writing about "The Snake Creek fossil quarries", states:

"The pockets from which the great bulk of the material has come are channel-beds excavated in and partly contemporary with fine-grained muddy sandstones, to which the name of Sheep Creek beds was applied when first found. These appear to be back-water sediment corresponding in age to horizons 1 and 2 of the channel-bed series [called by Matthew and Cook "Snake Creek" formation]; No back-water facies has been recognized for the Pliocene channel-beds (No. 3)" [the true Snake Creek channels at the top of the deposits].

Later Matthew (1924), writing about the relations of the Snake Creek and Sheep Creek beds, states that,

"the two [Snake Creek and Sheep Creek formations] representing different facies of the same formation or sequence of strata, in part contemporaneous, rather than two distinct formations. The Snake Creek beds are channel-fillings throughout (except near the top), and they fill and overlie eroded channels in the Sheep Creek beds, which are rather a fine-grained uniform back-water or flood-plain formation. But the stratigraphic and faunal evidence jointly show that the flood-plain beds are contemporary with at least the two older horizons (Miocene) of the channel beds. The third faunal horizon of the channel-beds [Snake Creek in original sense-1909] has no recognized flood-plain correlative."

Such an intermingled complex of contemporary sedimentation facies, as noted above from Matthew's papers, cannot be recognized as two separate and distinct stratigraphic formations by any criteria known to the writer. However, the original definition of the Snake Creek and Sheep Creek formations (Matthew and Cook, 1909) may be essentially valid, and it is in this sense that the writer proposes to continue the use of these names to apply to correctly differentiated formations. With this in mind, it should be noted that most if not all the so-called "Snake Creek" faunas from horizons 1 and 2 were collected from channel fills within the Sheep Creek formation. The Sheep Creek formation consists of channel fills, slack-water, and floodplain sediments (includes "Snake Creek" faunal horizons 1 and 2); whereas the higher and considerably later (middle to late Ogallala) true Snake Creek formation in the 1909 sense are all channel or ravine fills. These Snake Creek channel deposits may have filled and choked the Pliocene streams, which may have supplied the materials for quite widespread gravel and sand beds in the Ash Hollow or even the Sidney formation in the Ogallala group throughout areas to the south and southeast.

After the Sheep Creek "channels" or narrow valleys and ravines which had been eroded into older formations-in all known cases either the Harrison or the Marsland-had been filled with sediment, quite ex- 
tensively distributed beds of floodplain "marl" and eolian silt were deposited. The distribution of this heretofore unrecognized member of the Sheep Creek formation seems to have been nearly the same as that of the Marsland formation, and at present it overlies and extends beyond the limits of most of the Sheep Creek valley fills more or less throughout the areal extent of the Hemingford group, and in a few places it even rests on the Harrison formation.

The lower part of this upper clay member of the Sheep Creek formation consists of reddish-brown clay, quite plastic, with much colloidal material, in all about 30 to 35 feet thick. A middle zone (10 to 12 feet) of this lower elay is somewhat more silty and gritty, with silico-calcareous concretions throughout which greatly resemble loess concretions. This middle silty zone is somewhat lighter, being more pinkish to slightly greenish. Next above the lower reddish-brown clay occurs a middle zone of silty grayish and brownish lumpy to blocky fine-grained sandstone which includes a bed of bluish-gray volcanic ash at some places. This middle zone is fossiliferous (mostly fragmental bones) in places. This middle sandstone zone also is about 35 feet thick. A third and higher zone of greenish to reddish-brown silty, loess-like clay, similar to the lower clny zone, only about 15 feet thick occurs at a few places at the very top of this new "upper" member of the Sheep Creek. The total maximum thickness of this new member of the Sheep Creek formation is about 85 feet, and it is most fully developed in T. 29 and 30 N., R. 47 W., in southeastern Dawes County, Nebraska, a few miles northeast of Dunlap.

This upper member of the Sheep Creek generally has been included with and measured as a part of the Mrarsland formation, on which it rests unconformably at most places, where no separating Sheep Creek valley fill deposits occur to reveal the true relationship. No stratigraphic name is proposed for this new member by the writer. The privilege and responsibility of supplying a name for this formational subdivision belong to Richard C. Cady, of the United States Geological Survey, who is its discoverer and who is senior author of a publication in preparation on the geology and ground-water resources of Box Butte County, Nebraska."

Ogallala redefincd.-The Ogallala, originally named and defined by Darton (1898, 1903, 1905), is redefined as a group of four definite and mappable formations. The formational names-Valentine, Ash Hollow, Sidney, and Kimball-were not the choice of the writer alone, nor of any one individual. These names were agreed upon first in conference early in March 1936 in the State Geologist's office at Lincoln, Nebraska, by

\footnotetext{
A coperative project of the United States Geological Survey and the Conservation and Survey Division of the Cniversity of Nebraska.
} 
G. E. Condra, State Geologist of Nebraska; R. C. Moore. State Geologist of Kansas; Maxim K. Elias, of the Kansas State Geological Survey, and the writer. Agreement on Ogallala nomenclature also had been reached with C. Bertrand Schultz, Assistant Director, Nebraska State Muscum.

The appropriateness of the name Ogallala for the very widely distributed group of formations now included in this division scems not to have been fully appreciated. Ogallala has been applied more inclusively to all the Pliocene deposits of the Great Plains than any other name, which has gained recognition for any certain part of these deposits, except perhaps the very general and obsolete "Loup Fork". Ogallala seems to be the only name that actually has been applied to Pliocene formations from the oldest (Valentine) to the highest and youngest beds, the "Algal" limestone of Elias (1931), from South Dakota to Texas. Other terms, such as Valentine, Republican River, and Devil's Gulch include only a part of the group or formation, as the Ogallala has formerly been called, and all these named "beds" are for the most part restricted to the lower half or less of the "Ogallala". Not one of these other names could be redefined to include the entire group of formations. As a matter of fact, most of our knowledge of the Pliocene series in Nebraska and adjacent areas has been only piecemeal and mostly limited to the lower beds. Very little has been known of the character and faunal content of the upper part of the Ash Hollow, the Sidney, or the Kimball formation. Nost of the faunal collections from the higher formations or beds have never been correctly "tied in" to the general stratigraphic section of the Ogallala group.

The oldest and lowest formational subdivision of the Ogallala group is the Valentine formation, which was introduced by Barbour and Cook (1917). The validity and appropriateness of this name have been well stated by Johnson (1936). The writer is in full agreement with others (Johnson, 1936; Simpson, 1933) that the name "Valentine" is correctly applied only when used for the older unconsolidated sands and gravels in the basal part of the Ogallala.

A redefinition of "Valentine" has been proposed recently, thereby introducing a "Valentine Problem" into the literature. This incorrect application of the name Valentine in stratigraphic and palcontologic literature seems to have appeared first in papers by Stirton (1933) and Stirton and DeChardin (1934). Shortly thereafter Stirton and MeGrew (1935) definitely proposed a redefinition of Valentine. Johnson (1936) published a lucid and complete explanation of the problem. His paper should have settled the matter for all time, but a little later Stirton (1936) published another paper in which he continued the misapplica- 
tion of Valentine. The problem has been revived again by McGrew and Meade (1938) who persist in applying "Valentine" to a part of the geologic section which was not included in the original "Valentine beds" of Barbour and Cook (1917). The general disagreement with the proposal to redefine the Valentine is clearly indicated in papers by Lewis (1938), Colbert (1938), Johnson (1938), and the writer (Lugn, 1938) .

Nevertheless, Valentine is a very satisfactory name for all the more or less unconsolidated, fine gray sands, 175 to 225 feet thick, which constitute the lowest and oldest part of the Ogallala group. The Valentine formation occurs under the typical Ogallala "mortar beds." The "cap rock bed", a field term mentioned by Johnson (1936), is the lowest part of the "mortar beds" division of the Ogallala group. It is also almost exnetly the equivalent of the Krynitzkia fossil seed zone of Elias (1932, 1935; Chancy and Elias, 1936). It contains the "upper" of Stirton and MeGrew's (1935) three faunas, for which they proposed the name "Valentine" in a redefined sense. The Burge channel member of the Valentine formation occurs at the very top of the Valentine below the Krynitzkia seed zone, and the "Valentine fauna" comes from lower down in the formation (at about 80 feet above the Valentine-Brule clay contact southeast of Valentine, Nebraska).

The "mortar beds" division of the Ogallala group, which in the main is the only part exposed 3 in the "type locality" (?) near Ogallala, Nebraska, as defined by Elias (Stirton, 1936; Hesse, 1935), is known as the Ash Hollow formation, 100 to 250 fect thick. It contains the "eap rock bed" of the Krynitzhia coronoformis fossil seed zone, the "frngmental" vertebrate fossil zone which is the third and highest faunal zone of Stirton and MeCrew (1935)-mistakenly ealled by them "Valentine",-in the lower part of the formation. The remainder of the Ash Hollow formation includes most of the Biorbia fossilia fossil seed zone of Elins (1932, 1935; Chancy and Elias, 1936). This part of the formation also contains other faunal zones; and in the Valentine, Nebraska, area, near Burge, farther east in northeastern Cherry County, northern Brown County, and in Keya Paha County, the lower part of the Biorbia zone contains an abundant vertebrate fauna, which is higher than any mentioned by Stirton and MeGrew (1935). The association of Biorbia fossilia with this higher fauna was discovered by Morris Skinner and the writer in 1935. Fatunas correlative to the two in the lower part of the Ash Hollow formation in the Valentine, Nebraska, area and other still higher faunas are known from other areas in southern and southwestern Nebraska.

* The unconsolidated Valentire sands are now known to occur here under the "mortar beds," from data sectired by test drilling. 
The type section of this formation occurs in exposures in Ash Hollow Canyon southeast of Lewellen, Nebraska. The beds belonging to this formation in Ash Hollow Canyon, above about 55 feet of Brule formation, consist of layers of gravel and sand, silt, and fine sandy clay, with some beds of volcanic ash, all more or less indurated into hard caliche beds at fairly regular intervals. The total thickness of the beds believed to belong to the Ash Hollow formation, from the top of the Brule clay to the base of the overlying Sidney formation, is from 250 to 265 feet. This thickness includes a layer of conglomeratic limy sand and gravel which appears to lie below the Krynitzhia fossil seed zone, and this bed may be found to correlate with the Burge channel member of the Valentine formation. The Sidney gravel formation and remnants of the Kimball formation (Lugn, 1938) occur at elevations above the top of the Ash Hollow under the High Plains tableland level to the south of the canyon.

It has come to the writer's attention recently that the "Ash Hollow formation" is not a new or even recent name, as was at first supposed (Lugn, 1938). The term Ash Hollow formation was applied to exactly the same beds in Ash Hollow Canyon, the same location and exposures noted above, and they were said to "attain a thickness of over 250 feet" first by Henry Engelmann in 1858 or 1859 (Engelmann, 1876). It is a source of gratification that the recent redefinition (or reapplication) of the Ash Hollow formation by the writer and others matches perfectly in every way-lithology, thickness, location, and type section-the original definition of the "Ash Hollow formation" by Engelmann.

The third formation of the Ogallala group is known as the Sidney gravel from occurrences at Sidney, Nebraska. It ranges in thickness from 15 to 50 feet and is widespread in southwestern Nebraska, northeastern Colorado, and in parts of western Kansas. It is the upper part of the "Biorbia fossil seed zone", although Biorbia also occurs in the Kimball formation.

The type exposure of the Sidney gravel is located in the high bluff at the north side of the town of Sidney, Nebraska, a few rods west of the elevated water tanks which are a part of the Sidney water supply system. The gravel bed at this location is 20 feet thick and consists of crystalline sand and gravel ranging in texture from fine and medium river sand to pebbles and cobbles as much as 4 to 6 inches in diameter. Many of the pebbles are covered with a thin dark coating of mineral and clay which give to the deposit a characteristic darkish appearance in many fresh exposures. The gravel bed rests on a hard caliche sandstone or "grit" layer, belonging in the Ash Hollow, which is commonly quite characteris- 
tically pitted with old "fossil" potholes, some of which are as much as 5 or 6 feet decp and several feet in diameter. Many potholes may be observed below the gravel at the type exposure, but none at this place seem to attain the maximum size observed at a few other exposures.

The Kimball formation occurs typically developed above the Sidney gravel under the High Plains level for many miles north of Sidney. However, the relationships of the uppermost Ash Hollow beds, the Sidney gravel, and the beds of the Kimball formation, in a relatively small area north and northeast of the "water tanks" location at Sidney, are complicated by a zone of normal faulting which trends about west-northwest, more or less parallel to a conspicuous drainage.

The Sidney gravel in the main is a quite widespread sheet-like complex of channel deposits, but there are small areas where it is not developed; and, in such places, the Kimball formation rests directly on the Ash Hollow formation commonly with apparent lithologic continuity. The Sidney gravel is "pinched" out in this manner in one small area a few miles west of Sidney, Nebraska. Other less important and less widespread channel gravel deposits, similar in lithology to the Sidney gravel, also occur at lower horizons in the Ogallala group, especially in the middle and upper parts of the Ash Hollow formation.

The Sidney gravel is not fully differentiated from the Pleistocene "high terrace" in southern Garden, Deuel, and perhaps in parts of Keith countics. In this area, mainly between the North Platte and South Platte rivers, the gravel-covered Pleistocene high terrace level accords topographieally almost exactly with the stratigraphic position of the Sidney gravel in the Ogallala group. Some of the Sidney gravel has been reworked on this Pleistocene level; and, since the gravels of both ages are unconsolidated, it is impossible to make precise differentiation. At some locations, Pliocene (Sidney) fossil bones have been found in the lower part of the gravel, indicating that at these places at least the lower part of the gravel is sidney in place. Also, Sidney gravel occurs undisturbed in small areas still capped with Kimball caliche and algal limestone zones. Pleistoecne fossil bones have been found in the upper levels of the gravels at some points where not overlain by Kimball, and this indicates the position of the Pleistocene high terrace level and the reality of the reworking of part of the Sidney gravel.

$A$ fourth and uppermost formation of the Ogallala group is known as the Kimball formation from its typical occurrence at the highest remnant levels of the High Plains in Kimball County, Nebraska. The thickness of the Fimball formation ranges from 25 to 50 feet where present in its full development and consists of silt, clay, and fine sand, partly cemented 
with caliche, with one or two algal limestone beds at the top. It is pinkish to reddish and contains the fossil seeds of the genera Echinochloa, Panicum, and Biorbia (Elias, 1932; Chaney and Elias, 1936). The most striking feature of this formation is the occurrence, at the top of an algal limestone (Chorellopsis bradleyi Elias) (Elias, 1931, p. 136-141). The formation is also widespread and generally is not overlain by later deposits, except small amounts of wind-blown silt or loess material.

The Kimball formation in general consists of three beds or zones. The lowest bed, resting with apparent conformity on the Sidney gravel at most places, is a grayish and pinkish "grit" or caliche sandstone, composed of fine to coarse sand, with small granule pebbles in some places. It may contain nodular bands of milky chert or chalcedony, generally fairly hard and indurated, forming a more or less prominent ledge. This lowest zone ranges from 5 or 10 to 15 feet in thiekness. The middle bed of the Kimball formation, 18 to 22 feet thick, consists of fine silty sand, pinkish and brownish, and for the most part soft. The uppermost or algal limestone zone generally is one conspicuous bed of whitish hard algal limestone 2 to 3 feet thick; but it may consist of two or even three algal limestone layers with interbedded soft pinkish to grayish fine silty sand and marly clay, in all ranging up to 12 to 15 feet in thickness. Milky chert also may be a constituent of this uppermost bed of the Kimball formation, and minute siliceous structures strongly suggestive of spore cases of the algal genus Chara are also present.

The lower part at least of the Kimball formation generally contains Biorbia fossil seeds and certain other fossil seeds, as noted above, which Elias believes to be restricted to the uppermost beds of the Ogallala group. A typical exposure of the Kimball formation occurs at the High Plains level about 2 miles south of Kimball, Nebraska, in the vicinity of the adjoining corners of sections $5,6,7$, and $8, T .14$ N., R. $55 \mathrm{~W}$.; and many other good exposures occur from this point southward into Colorado. Typical development of the Kimball formation, where the beds are well exposed, may be seen also at these locations: south of Harrisburg, Nebraska, in Banner County, in the S. E. $1 / 4$, sec. 26, T. 18 N., R. 56 WV.; at 9 miles east of Sidney, Nebraska, in Cheyenne County, the S. W. 1/4, see. 23, T. 14 N., R. 48 W.; near the Lone Star School in Colorado, 20 miles south of Kimball, Nebraska; and at innumerable other locations in southwestern Nebraska, northeastern Colorado, and western Kansas.

The stratigraphic table of Tertiary formations of Nebraska (Table 1) provides a brief summary of the Tertiary stratigraphy in this State and a résumé of the classification and nomenclature of these formations, in use at the present time. 
TABIe 1.-Tertiary formations of Nebraska*

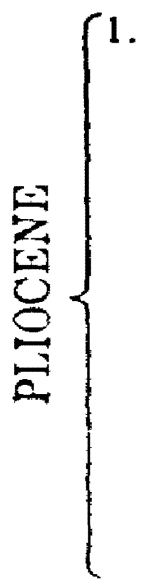

(?)

\section{UNCONFORMITY}

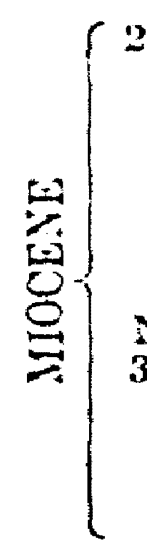

2. Homingford group $250^{\prime}-100^{\prime}$

(1) Sluep Crock formation 140'-300'

Stipidium and Berriochloa fossil secds.

Unoonformity

\section{UNCONFORMITY}

3. Arikaree eroup $700^{\circ}-500^{\circ}$

(1) Iatrison formation $200^{\circ}$

Dacmonelix linds at the top.

(2) Monroe Creek formation $375^{\circ}$

(3) Gering formation $100^{\circ}-200^{\circ}$

Ogallala group $300^{\prime}-500^{\prime}$

(1) Kimball formation 25'-50'

Echinochloa, Panicum, and Biorbia fossil secds, and Algal limestone.

(2) Sidney gravel $15^{\prime}-50^{\prime}$

Upper part of Biorbia seed zone.

(3) Ash Hollow formation $100^{\prime}-250^{\prime}$

Main part of Biorbia fossil seed zone, and several faunal horizons in Biorbia zone; Krynitzkia seed zone in the lower part ("ap rock bed"). "fragmental" vertebrate fossil zone ("Valentine" of Stirton and McGrew).

(1) Valentine formation $175^{\prime}-225^{\prime}$

Stipidium foseil seed zone; Burge channel member and the "Burge" fauna at the top; the "original" Valentine fauna occurs well down in the formation.

(2) Narkland formation (old "Upper Harrison") 125'-200'

Note: IIorizon of the folding of the Arate Anticline and many other structures.

UNCONFORNITT

White liver frouy $500^{\circ}-700^{\circ}$

(1) Hrule cling $500^{\circ}-600^{\circ}$

Leptaluhenia and Orcodon beds with zones of channel sandstones.

(2) Chatron formation $50^{\circ}-150^{\circ}$

Titanotheritm beds.

\section{TNCONFORMITY}

Mainly Cretaceous shale formations: Pierre, etc.

Fort: Crltis sede oceur throughout all of the Tertiary formations noted above. Coltis hateleri has ben deseribed as from the White River group: most of the Cellis slones from hicher formations are generally referred to the species willistoni. The genus Stipidium, prhaps sereral species, oerurs also in the higher formations of the Oeallals tromp ssebeiated with the "index" fossil seds of these zones. The Miocenelliocen contart is atill undecided upon as indirated above.

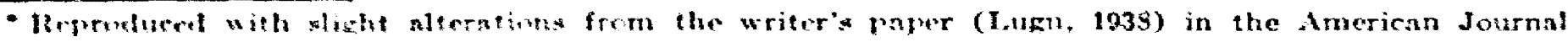
if siriciter.

\section{ACE OF TFRTIARY FORMATIONS IN NEBRASKA}

It is not the intention of the writer in the present paper to try to fix definitely the age of the Tertiary formations in Nebraska with respect to the accepted epochs of the Tertiary period, except in a general way. At present it is impossible to assign exact age to any of the formations 
discussed herein, until the vertebrate paleontologists can agree on criteria to be applied in determining the limits of all the Tertiary epochs.

It has been possible to determine the age relations of the several groups and formations largely by field study, and the sedimentation secuence and stratigraphic succession of beds have been worked out with considerable certainty. The areal distribution of the stratigraphic groups and formations has been mapped in some detail. The relative ages and positions in the geologic column of all the named sedimentary and stratigraphic units are now understood with greater accuracy than ever before. These are the results in part presented in this paper, and they are considered of far greater importance at present than the assignmenti of exact age to any particular beds, desirable as that also may be. But, until agrement is reached on what criteria shall be used to differentiate, for example, Miocene from Pliocene, age assignments to formations cannot be made with any certainty of agreement among either stratigraphers or paleontologists.

No deposits of Eocene age are recognized in Nebraska. Considerable confusion exists in regard to the age of the Marsland and Sheep Creek formations. This has been discussed earlier in this paper, but the confusion regarding the age of the Sheep Creek formation is due largely to the fact that many vertebrate fossils supposedly collected from the Sheep Creek beds actually have come from the older, underlying Marsland formation, or even from the still older Harrison beds. The causes of confusion regarding the age of the Snake Creek beds have been noted, but fundamentally the main source of difficulty has been the fact that the suake Creek faunal horizons 1 and 2 actually occur in the Sheep Creck formation and only faunal horizon 3 is in the Snake Creek formation. The uncertain age of the Valentine formation is due largely to lack of sgreement on the criteria to be applied in differentiating Pliocene from Viocene.

It will be necessary to know more about the sedimentary succession and stratigraphic relations of all the beds throughout the Tertiary system than is understood at present, in order to understand the age relations and succession of fossils and faunas, before agreement can be expected on the exact age and epoch divisions of the Tertiary period. Therefore, only very tentative age assignments are made for the Tertiary formations in Nebraska in this paper. Table 2 represents only the tentative opinion at the present time of the Nebraska State Geological Survey, the Nebraska state Museum, the writer, and numerous other geologists and palcontologists. The table should not be regarded as indicating any final or settled opinion. It is subject to revision as new data may require at any time. 
THE "HARRISON" IN THE GOSIEN HOLE AREA

The geology of an area lying mostly west and northwest of Scotts Bluff County, Nebraska, known as the "Goshen Hole Area, Wyoming",

TABLE 2.-Tentative age assignments to Tertiary formations in Nebraska

\begin{tabular}{|c|c|c|}
\hline 穿 & Ogatlala & $\begin{array}{l}\text { Kimball formation (very late upper Pliocene) } \\
\text { Sidney gravel (upper Pliocene) } \\
\text { Snake Creek formation (middle to late Pliocene) } \\
\text { Ash Hollow formation (middle Pliocene) } \\
\text { Valentine formation (early Pliocene) }\end{array}$ \\
\hline \multirow{2}{*}{ 穿 } & Ilemingford & $\begin{array}{l}\text { Sheep Creck formation (late upper Miocene) } \\
\text { Marsland formation (early upper Miocene) }\end{array}$ \\
\hline & Arikaree & 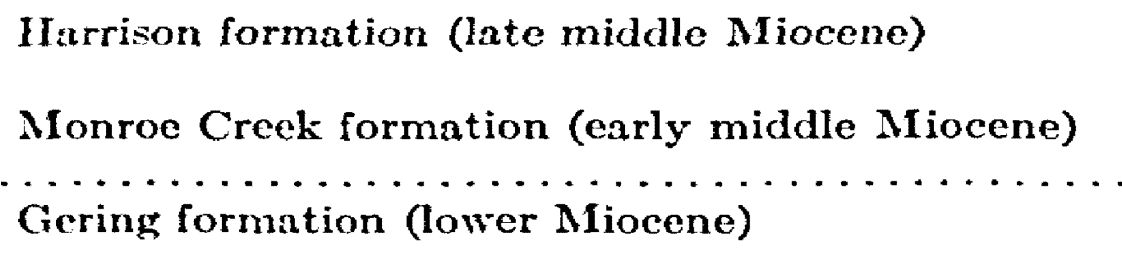 \\
\hline \multirow{2}{*}{ 言 } & \multirow[t]{2}{*}{ White River } & $\begin{array}{ll}\text { Brule clay } & \text { Leptauchenia beds } \\
\text { Oreodon beds }\end{array}$ \\
\hline & & Chadron formation or Titanotherium beds \\
\hline
\end{tabular}

has becn described and mapped by Schlaikjer (1935). A large portion of this aren is mapped as "Lower Harrison". Schlaikjer states:

"This formation constitutes the high upland table lands of the area and is exposed principally on Sixty-Six Mountain. Bear Creck Mountain, in the southwestern corner of the area and in the vicinity of Deer and Six Mile creeks south of old Fort Laramie. Its maximum thickness is approximately four hundred feet, and it is mainly composed of light to dark gray unconsolidated sand and sandstones in the form of channels and concretions. . The lower IIarrison formation rests with disconformity and unconiormity on the Brule, and its lowest limits are generally marked by channel deposits".

Schlaikjer states at other places that "a duplicate sequence occurs" at Eagle's Nest and at Signal Butte and that at these points in Nebraska "the lowermost Harrison is composed of rather well stratified sands with only very thin sandstone layers".

Later (p. 118) he discounts the Gering formation, stating, 
"I have inspected the Gering formation at the type locality south of Gering, Nebraska, and have made a preliminary study of it from that locality westward to Wyoming. It appears to be nothing more than an exaggerated eastward extension of the same conditions that prevail at the base of the lower farrison in the Goshen Hole Area. In other words, the Gering represents only a local phase of the lower Harrison ...".

It is not clear just what is meant by "an exaggerated eastward extension of the same conditions. . . ." The Gering formation is now considered the basal part of the Arikaree group.

Schlaikjer does not explain what became of the Monroe Creek formation in the Goshen Hole Area, but his descriptions, recorded sections, and the personal inspection by the writer and others in the field clearly indicate that Schlaikjer's "Lower Harrison" is in reality the Gering formation next above the unconformable contact on the Brule and the Monroc Creek formation in nearly the whole area. Probably the beds, which he calls "Upper Harrison" (now Marsland), "at the heads of Deer and Cherry creeks" are in reality true Harrison (old lower Harrison). The writer has personally examined the exposures at the heads of Deer and Cherry creeks, and Harrison beds are probably present here even though the lithology of the entire 400 feet or more of exposed section in this vicinity is not typical of all the zones which are probably present. There is some paleontological evidence of the presence of somewhat higher beds here than seem to occur generally in other parts of the area. On the other hand, there is also a possibility that faunas lived in the Goshen Hole Area earlier than almost identical faunas found in higher (?) beds in certain other areas farther to the northeast. Geographic distribution, which was controlled by general climatic conditions and water supply, has no doubt greatly affected the distribution of faunas in time almost as much as in geography. Continuity of significant lithologic zones is probably just as safe a criterion of contemporaneity of sedimentation as identity of fossils. The Gering and Monroe Creek formations with perhaps some Harrison formation are distinct lithologic zones and appear to extend into the Goshen Hole Area. It seems more logical to accept the continuity of the lithology as indicative of formational identity than to assume rather extreme facies change in lithology on the basis of paleontological evidence which may questionably indicate a somewhat later age for the beds.

Both Signal Butte and Eagle's Nest, points in Nebraska noted above as referred to by Schlaikjer, are capped with only the Gering formation above the Brule clay. The east end of Sixty-Six Mountain, which extends into Scotts Bluff and Banner counties, Nebraska, has Gering and Monroe Creek formations only above the Brule but does not have any Farrison formation on it, at least not in Nebraska. Remnant patches of Harrison (old lower Harrison) formation occur in some places on Wild Cat Ridge 
farther east in Scotts Bluff, Banner, and southern Morrill counties; and a little wedge of Harrison, up to 20 to 40 feet thick, occurs at the Wyoming-Nebraska state line in western Banner County, where it extends nearly across T. 18 N., R. 58 W., in the bluffs between the Monroe Creek and Ash Hollow (Ogallala) formations.

Schlaikjer nowhere indicates that he intended to redefine the Harrison or to discard the Monroe Creek. He apparently thought that the Monroe Creek either did not occur in his area or that it correlated with and was included in the lower Harrison formation. He does not make this clear. In any ease, a conformable Harrison (lower Harrison) over Gering would be anomalous, since in aseending order the Gering, Monroe Creek, and Inarison formations lie superimposed in the Pine Ridge and elsewhere. They are less easily distinguished toward the east along the Pine Ridge, that is, from Chadron castward across northern Sheridan County, than they are westward across Dawes and northern Sioux counties. To the east and in South Dakota these formations correlate with the Rosebud.

The upper part of the Monroe Creek formation, about 100 to 110 fect thick, is exposed about 4 miles east of Agate where it is brought high in the structure of the Agate anticline. Here, it is overlain by the typical Harrison (lower Harrison) formation, up to 50 feet or more thick at the location of the old Agate test well for oil. Schlaikjer states that he has studied the lower Miocene "from the Rosebud-Pine Ridge district of South Dakota southwestward across Nebraska, via Chadron uml Agate, into the Scotts Bluff-Goshen Hole areas. . ." Remembering that the Harrison formation is thin or "pinched out" and in some places absent altogether east of Chadron, Nebraska (sce Pl. 1), the writer believes that Schlaikjer either did not distinguish the Harrison (lower Harrison) from the Monroe Creek in the Pine Ridge or that he mistook the Monroe Creek formation for the Harrison. He might then easily have thought that the exposed 100 feet or more of Monroe Creek formation at Agate was the Harrison (lower Harrison) and that the overlying beds belonged naturally to the upper Harrison (now Marsland). As a matter of fact, there are no occurrences of Marsland (upper IIarrison) at Agate. Some remmants of the Marsland formation do occur to the southeast and others to the northeast of Agate. A mistaken identity of formations as stated above might easily occur. It would then have been most natural for Schlaikjer to identify the Monroe Creck-Gering part of his Goshen Hole exposures as lower Harrison (nowHarrison), and the occurrences of

"light to dark gray sands and sandstones which contain some lenticular beds of clay and which, at certain levels are made up of more than fifty per cent of plant 
at the heads of Deer and Cherry crceks, as upper Harrison (now Marsland). In any case, Schlaikjer (1935) described and mapped the Gering and Monroe Creek formations as "lower Harrison", and his "upper Harrison" probably is true Harrison or old "lower Harrison". Gering, Monroe Creek, and remnant patches of Harrison formation occur in the "Coshen Hole Area" in just about the same way as they occur to the east in Nebraska, where, however, they are less deformed by structure.

\section{OBSOLE'TE NAMES}

General statement.-Certain obsolete names for "beds" or formations have attained some use, and a number of them have served a useful purpose; in some cases, their usage has been abused, and, because of too general or too divergent application to widely separated "beds", either stratigraphically or geographically, they have had to be abandoned. Four such outstanding Nebraska names are Loup Fork, Nebraska, Rosebud, and Republican River. The terms Loup Fork and Loup River have been confused and often used interchangeably; "Loup River" has been considered the higher and younger division. Both names are now abandoned by the Nebraskai Geological Survey.

"Loup River"-Loup Fork".- Simpson (1933) has summarized the "Loup River"-"Loup Fork" as follows:

"Loup River, Loup Fork: Obsolete terms once in general use for part or all of the Miocene. The history of these unfortunate names is summed up by Osborn and Hathew (1909). The 'Loup River' was defined by Meek and Hayden in Nebraska 2s a formation, in largest part probably of Pleistocene age, but also made to include all the adjacent deposits down to the White River. Leidy continued to confuse the true or type 'Loup River', Pleistocene, with the much older Upper Miocene or Lower Plocene ('Nebraska'). From this the name was generalized by Cope, in the form Loup Fork' as an epoch name in which he placed the Santa Fé. The name continued for a time in general use and the most diverse horizons were referred to it, from what is now considered Lower Miocene to the Lower Pliocene. It has no bistoric authenticity, unless 'Loup River' be retained for a Pleistocene horizon, and so accurate and exact meaning, so that it has necessarily been discarded for the sost part, although occasionally employed for the Nebraska or Valentine stage".

"Loup River" has not been retained or resurrected for any part of the Pleistocene of Nebraska (Lugn, 1935, p. 127, 188-195). Osborn and Natthew (1909), noted above by Simpson, indicate that "Loup Fork' of Leidy, Marsh, also of Scott and Osborn . . ." applied mainly to the "Ogallala formation", also to the "Ogallala and Arikaree of Darton (in part)", and that it was equivalent in part to other formations in other areas, for example: Deep River, Pawnee Creck, Mascall, Santa Fé, Clarendon beds, Madison Valley beds, Archer, Rattlesnake, and Blanco; and to the Pontian and Eppelsheim of Europe. Osborn and Matthew also diccuss the use of these terms by "Mcek and Hayden, 1861-62", by Hayden, and by Hayden and Leidy. 
"Loup River" is the original name and "Loup Fork" was its synonym for many years. Hayden (1869) and his associates applied the name "Loup River beds" to the part of the "Tertiary Rocks of Nebraska" which they regarded as "Pliocene". However, their "Pliocene" included everything now in the Ogallala and Arikaree groups down to the White River. This was also the lower division of Hayden's "bed F" (about equal to Ogallala and perhaps certain Pleistocene deposits in northern Nebraska) and "bed E" (in the main the present Arikaree group). The upper part of Hayden's "bed $F$ " is Pleistocene loess (Loveland and Peorian), "most fully developed along the Missouri River from the mouth of the Niobrara to St. Joseph. Also in the Platte Valley and on the Loup Fork".

Nobraska beds of Scott.-Scott (1893) introduced the name "Nebraska" or "Nebraska beds" for the middle part of the "Loup Fork" as he understood it in 1893. He states:

"Whe grcat Loup Fork formation has been much misunderstood, partly because it has not always been distinguished from the much later Equus beds, and partly because the separate horizons into which it may be divided have but lately been worked out. Of these there are three. The oldest is the Deep River horizon of Montana (Ticholeptus bed of Cope) and is characterized especially by a number of aberrant oreodonts and some peculiar genera of horses. . . The second or middle horizon of the Ioup Fork covers a vast area from Nebraska to Mexico, and has yielded a very larie number of mammals. Of these the most characteristic is, perhaps, the antelonelike gemus Cosorys. An appropriate geographic name for this subdivision would be "Nebriska'. . . The latest of the three horizons of the Loup Fork may be called the Palo Duro, -

IIe thought that the Decp River and Nebraska horizons "belong unquestionably to the Miocene". Simpson (1933, p. 103) says of the Nebraska beds:

"Ncbraska: Proposed by Scott (1S91A) for deposits of western Nebraska apparently synchronons with those now called Valentine (which see). Hatcher (1902) and Peterson (1906) applied the name to much older beds now included in the Upper Irarrison." The name is not in current use in either sense. ("Nebraskan' is a stage of the Pleistocene.)"

Roscbud.-Roschud is the name applied to about 500 feet of pinkish sandstone and silty" clay, the "Lower Miocene of southern South Dakota", and it has been used to some extent for the bluff-forming layers of the eastern part of the Pine Ridge, mainly in northern Sheridan County, Nebraska. The name was applied by Matthew and Gidley (1904). Matthew tentatively correlated the Rosebud with the lower Miocene of western Nebraska, that is, with the Harrison. In a general way, this is correct. However, all the formations and horizons of the Pine Ridge farther west in northern Sioux and Dawes counties have now been traced into the Rosebud of northern Sheridan County. The Rosebud in north-

\footnotetext{
Crprer IIarrison. as explained, is now the Marsland formation.
} 
ern Sheridan County encompasses all that is present of the following formations: Gering, Monroe Creek, Harrison (old lower Harrison), and at least the lower part of the Marsland formation (old upper Harrison). The Harrison (old lower Harrison) is nowhere in this area present in its full development. Excluding small remnant lenses, it was largely removed by erosion over the anticlinal arch which extends from the vicinity of the northwestern corner of Sheridan County southeastward near Hay Springs and across the State perhaps to connect up with the "Cambridge anticline" in southern Nebraska. The age of this folding and erosion seems to be post-Harrison (old lower Harrison)-pre-Marsland (old upper Harrison).

The Gering and Monroe Creek formations seem almost fully developed across northern Sheridan County except at the extreme east where both formations terminate. However, the Gering is indistinguishable from the Monroe Creek formation in this area on the basis of lithology alone, and the Gering is mapped with the Monroe Creek on Plate 1. The Gering horizon is known to be present because of the occurrence of "Gering" vertebrate fossils. Because of the erosion and "pinching out" of the Farrison in this area, the Marsland formation rests in contact with the upper part of the Monroe Creek in many places. (See Plate 1.)

Therefore, in so far as recognized in Nebraska (northern Sheridan County), the Rosebud buff and pinkish silty sandstones and clays correlate with the Gering, Monroe Creek, remnants of Harrison, and the lower part of the Marsland formation. This is not contrary to the opinions of others (Cook, 1915; Cook and Cook, 1933), but in most other discussions the question of correlation generally is narrowed down to a correlation of faunas and almost never includes the main formational units. Nevertheless, Perisho and Visher (1912) have indicated almost exactly the same correlation for the Rosebud as given above. O'Harra (1920) also has written of the Rosebud and other Tertiary formations of South Dakota and has indicated the same correlation for the Rosebud.

The term Rosebud is more or less superfluous in Nebraska. It has never been widely used within the State, and, in so far as Nebraska is concerned, it may be considered obsolete. However, the writer would not censure the retention of "Rosebud" in South Dakota and northern Nebraska as an inclusive term for the correlative formations where they are too indistinct for differentiation. It represents a facies of these formations in a certain area where finer differentiations are difficult.

Republican River.-Regarding Republican River, Simpson (1933, p. 107) states:

\footnotetext{
"Republican River: Lower Pliocene of northwestern Kansas, and, by extension, the corresponding stage of the Pliocene generally. The beds were extensively ex-
} 
plored, especially for Marsh, and a large fauna is known, but there is no recent faunal or stratigraphic revision aside from such syntheses as that of Osborn and Matthew (1909) or references in describing individual fossils or faunas of similar age. It was generally placed in the 'Loup Fork', 'Upper Loup Fork', or 'Orallala'. but the more definite local name has been consistently applied by Matthew and is now renerally accepted. Mathew (in Osborn and Matthew 1909) tentatively considered it as slightly later than the 'Nebraska' (Valentine), later reaffirming this more positively (1924B). Most recently, Matthew and Stirton (1930B) have. in passing, suggested that the Republican River may be in part composite, with the beds on Sappa Creek and elsewhere to the southeast later than those on Driftwood Creek and to the north. They continue to place the fauna, as a whole, as younger than Valentine, adding that it seems to be slightly older than their Goodnight-Hemphill (and henee equivalent to Clarendon)".

The exposures generally referred to the Republican River beds in southwestern Nebraska and adjoining portions of Kansas are now known to belong to the lower part of the Ogallala group, that is, they are equivalent to the upper part of the Valentine formation and the lower part of the Ash Itollow formation. The Republican River is neither a lithologic nor a stratigraphic unit, and the fauna, so called, is a "composite" and "mixcd" one. The "Republican River" exposures should be referred to their proper formational horizons, and "Republican River" has been abandoned by the Nebraska Geological Survey.

As noted by Simpson above, Matthew and Stirton considered the fauna "as younger than the Valentine". This is in all probability correct, as the fossil-bearing horizon on Driftwood Creek, southwest of McCook, Nebraskn, seems to correlate almost exactly with the Burge channel horizon at the top of the Valentine formation in northern Nebraska. The fossil-bearing channel deposits at Driftwood Creck also occur below the "caprock bed" and the Krymitzkia fossil seed zone, the same position as occupied by the Burge channel member of the Valentine. The "Valentine" fauma occurs in some places as much as 100 fect or more below the Burge level. The "heds on Sappa Creek" and other places are mostly higher and later than the fossil-bearing horizon on Driftwood Creek, and these higher horizons belong to the lower part of the Ash Hollow formation, the Krymitzkia and lower part of the Biorbia seed zones, all definitely higher stratigraphically than the level of the Valentine fauna at Valentine, Nebraska.

Considering all available evidence, it seems certain that the "Republican River" represents a composite of lithologic and faunal horizons and should be abandoned as a stratigraphic term. Furthermore, many of the fossil finds were obtained from the unconsolidated sands and gravels in pits under the lower slopes of the valleys west and southrest of MrCook. Nebraska. Some fossils have been collected from higher beds, from the "mortar beds" along the sides of the valleys. The sand and gravels belong to the upper part of the Valentine formation, and the "mortar beds" levels contain the Krynitzkia fossil seed zone and the 
lowermost part of the Biorbia fossil seed zone, all in the lower part of the tsh Hollow formation. Therefore, the fauna is much mixed, and also the described and published sections do not include the lower (Valentine) beds in the exposures. Thus it seems that fossils from as low as the Burge member or even lower in the Valentine formation have been credited as coming from "mortar beds" levels in the lower part of the Ash Hollow formation, all as "Republican River".

"Republican River" could not be redefined in any way to include all of the Ogallala group; it is not synonymous with Ogallala and could not be substituted for Ogallala.

\section{CONCLUSIONS}

The writer believes that the classification of the Tertiary system in Nebraska presented here is a workable classification, subject, however, to revisions as future more detailed and more exact knowledge may require; that the stratigraphic units now acceptable to the Nebraska State Geological Survey and employed by it for mapping are satisfactory and as generally acceptable under present circumstances as could be expected; also that the nomenclature presented here very properly may be applied for purposes of stratigraphic description and mapping to most of the Tertiary deposits of the High Plains. It seems probable that the use of fossil seed zones may well mark a new epoch in Tertiary stratigraphic investigation for nearly all late Miocene and Pliocene sediments in the Great Plains Region. The application of "stratigraphic methods" to the interpretation of Tertiary sedimentation and the age relations of deposits and contained faunas contributes much to the more accurate determination of faunal successions and animal evolution.

\section{WORKS TO WHICH REFERENCE IS MADE}

Ahley, G. H., et al. (1033) Classification and nomenclature of rock units, Geol. Soc. Am., Bull., vol. 44, p. 423-459; Am. Assoc. Petrol. Geol., Bull., vol. 17, p. $843-868$.

Barbour, E. H. (1917) The Boyd County Mastodon Tetrabelodon Osborni, Nebr. Geol. Survey, vol. 4, pt. 30, p. 499-512.

-, and Cook, H. J. (1917) Skull of Aclurodon platyrhinus, sp. nov., Nebr. Geol. Survey, vol. 7 , pt. 19 , p. 173-180.

Chaney, R. W., and Elias, M. K. (1936) Late Tertiary floras from the High Plains, Carnegie Inst. Washington, Publ. no. 476, 72 pages.

Colbert, E. H. (1938) Remarks on the use of the name "Valenline", Am. Jour. Sei., 5th ser., vol. 36, p. 212-214.

Cook, H. J. (1915) Notes on the geology of Sioux County, Nebraska, and vicinity, Nebr. Geol. Survey, vol. 7, pt. 11, p. 59-75.

- and Cook, M. C. (1933) Faunal lists of the Tertiary Vertebrata of Nebraska and adjacent areas, Nebr. Geol. Survey, 2d ser., Paper 5, p. 11, 28-31. 
Cragin, F. W. (1896) On the stratigraphy of the Platte series, or Upper Cretaceous of the Plains, Colo. College Stud., vol. 6, p. 49-52.

Darton, N. H. (1899) Geology and water resources of Nebraska west of the one hundred and third meridian, U. S. Geol. Survey, 19th Ann. Rept., pt. 4, p. 719-785.

(1903) Gcology and water resources of Nebraska west of the one hundred and third meridian, U. S. Geol. Survey, Prof. Paper 17, 69 pages.

(1905) Geology and underground water resources of the central Great Plains, U. S. Geol. Survey, Prof. Paper 32, 405 pages.

Elias, M. K. (1931) Geology of Wallace County, Kansas, Kansas Geol. Survey, Bull. 18, p. 136-141.

(1932) Grasses and other plants from the Tertiary rocks of Kansas and Colorado, Univ. Iínsas, Bull., vol. 33, no. 10, p. 333-367.

(1035) Tertiary grasies and other prairie vegetation from High Plains of North America, Am. Jour. Sci., 5th scr., vol. 29 , p. 24-33.

Ingclmann, IIenry (1S76) Report on the geology of the country between Fort Leavcnuorth, K. T., and the Sicrra Nevada, near Carson Vallcy; Appendix I, of a Report of cxplorations across the great basin of the Territory of Utah for a dircet wagon-route from Camp Floyd to Genoa, in 1859, by Captain James Ifervey Simpson, Engrincer Department, U. S. Army (Govt. Printing Ottice, Wash.), p. 213-336. Sce especially p. 260-262, 283.

IIatcher, J. 13. (1902) Origin of the Oligocene and Miocene deposits of the Great Plains, Am. Philos. Soc., Pr., vol. 41, p. 113-131.

Inyden, F. V. (1869) Geology of the Tertiary formations of Dakota and Nebraska, Introduction to Joseph Leidy's monograph Extinct mammalian fauna of Dakota and Ncbraska, Phila. Acad. Nat. Sci., Jour., vol. 7, 2d ser., p. 9-21.

Hesse, C. J. (1935) A vertcbrate fauna from the type locality of the Ogallala formaCion, Univ. Kansas, Bull, vol. 36, no. 8, p. 79-117.

Johnson, F. W. (1936) The status of the name "Valentine" in Tertiary geology and preteoneology, Am. Jour. Sci., 5th ser., vol. 31, p. 467-475.

(193S) Further comments on the usage of "Valentine", Am. Jour. Sci., 5th ser., vol. 36, p. 215-219.

I.ewis, G. E. (193S) Commentary on McGrew and Meade's paper, Am. Jour. Sci., 5th ser., vol. 36, p. 20 S-211.

Lugn, A. L. (1935) The Plcistocene gcology of Nebraska, Nebr. Geol. Survey, Bull. 10. $2 \mathrm{~d}$ scr., 223 pages. Scc espccially p. 30-31, 8S-127, 1SS-195.

(1938) The Nebraska State Geological Survey and the Valentine problcm, Am. Jour. Sci., 5th ser., vol. 36, p. 220-228.

McGrew, Paul, and Meade, G. E. (193S) The bearing of the Valentine arca in continental Miocene-Pliocenc correlation, Am. Jour. Sci., 5th scr., vol. 36. ?. $197-207$.

Matthew. W. D. (1015) Contributions to the Snake Creck fauna, Am. Mus. Nat. Hist.. Bull., vol. 3S, p. 1S3-229.

(1023) Stratigraphy of the Snake Crcek fossil quarries and the corrclation of the faunas (abstract), Geol. Soc. Am., Bull., vol. 34, p. 131.

(1924a) Third contribution to the Snake Creek fauna, Am. Mus. Nat. Hist., Bull.. vol. 50, p. 59-210.

(1924b) Corrclation of the Tertiary formations of the Great Plains, Geol. Soc. Am., Bull., vol. 35, p. 743-754.

, and Cook, H. J. (1909) A Pliocene fauna from western Nebraska, Am. Mus. Nat. Hist., Bull., vol. 26, p. 361-114. 
Matthew, W. D., and Gidley, J. W. (1901) New or little known mammals from the Miocene of South Dakota, Am. Mus. Nit. Hist., Bull., vol. 20, p. 241-26S.

- and Stirton, R. A. (1930) Equidae from the Pliocene of Texas, Univ. Calif. Publ., Bull. Dept. Geol. Sci., vol. 19, p. 349-396.

0Harra, C. C. (1920) The White River Badlands, So. Dak. School Mines, Bull. 13, 181 pages. (See Rosebud p. 45-46.)

Osborn, H. F. (1929) The titanotheres of ancient Hyoming, Dakota, and Ncbraska, U.S. Geol. Survey, Mon. 55, vol. 1, p. 1-140.

- , and Matthew, W. D. (1909) Cenozoic mammal horizons of western North America, U. S. Geol. Survey, Bull. 361, 138 pages. See p. 76-84.

Perisho, E. C., and Visher, S. S. (1912) The geography, geology, and biology of southcentral South Dakota, So. Dak. Geol. Biol. Survey, Bull. 5, p. 49-53.

Peterson, O. A. (1906) The Miocene beds of western Nebraska and eastern Wyoming and their vertebrate faunae, Ann. Carnegie Mus., vol. 4, p. 21-72. See p. 21-24.

Schlaikjer, E. M. (1935) Contributions to the stratigraphy and palcontology of the Goshen Hole Area, Wyoming, Pt. IV, New vertebrates and the stratigraphy of the Oligocene and early Miocene, Harvard College, Mus. Comp. Zool., Bull., vol. 76, no. 4, p. 98-120, and map following p. 189.

Schultz, C. B. (1938) The Miocene of western Nebraska, Am. Jour. Sci., 5th ser., vol. 35, p. $441-444$.

Scott, W. B. (1894) The later Tertiary lacustrine formations of the West (abstract), Geol. Soc. Am., Bull., vol. 5, p. 594-595.

Simpson, G. G. (1933) Glossary and correlation charts of North American Tertiary mammal-bearing formations, Am. Mus. Nat. Hist., Bull., vol. 67, Art. III, p. 79-121.

Stirton, R. A. (1933) A critical review of the Mint Canyon mammalian fauna and its correlative significance, Am. Jour. Sci., 5th ser., vol. 26, p. 569-576.

(1936) Succession of North American continental Pliocene mammalian faunas, Am. Jour. Sci., 5th ser., vol. 32, p. 161-206. See especially p. 177-178.

$\longrightarrow$, and De Chardin, P. T. (1934) A correlation of some Miocene and Pliocene mammalian assemblages in North America and Asia with a discussion of the Mio-Pliocene boundary, Univ. Calif. Publ., Bull. Dept. Geol. Sci., vol. 23, no. 8, p. $277-290$.

- and McGrew, Paul (1935) A preliminary notice on the Miocene and Pliocene mammalian faunas near Valentine, Nebraska, Am. Jour. Sci., 5th ser., vol. 29, p. 125-132.

Vxinersity of Nebraska, LinCOLN, Nebraska.

MiNescaipt Received ay the Sechetaky of THE SOCIETY, Decenaen 24, 1938.

Ptalished hith the permission of the State Geologist of Nebraska. 